\title{
Depressive Symptoms and Oral Contraceptives
}

\author{
BRENDA N. HERZBERG, ${ }^{*}$ M.B., M.R.C.P., D.P.M. ; ANTHONY L. JOHNSON, $†$ B.SC. ; SUSANNAH BROWN, $\ddagger$ M.Sc.
}

Cummary: Of 261 women who completed a self-rating scale for measuring depression, 168 were taking oral contraceptives and 93 were using physical methods of contraception. Of the group of women taking oral contraceptives $6.6 \%$ were more severely depressed than any of the control group. There was a significant variation in the depth of depression related to the day of the menstrual cycle in the control group. This association was not found in the oral contraceptive group, where premenstrual depression was limited to the one or two days preceding menstruation.

Women taking a contraceptive containing lynoestrenol $2.5 \mathrm{mg}$. and mestranol $0.075 \mathrm{mg}$. showed a significantly increased incidence of pessimism, feelings of dissatisfaction, crying, and tension, compared with women taking other oral contraceptives and the control group.

\section{Introduction}

Depression is a known side-effect of oral contraceptive therapy (Kaye, 1963; Hauser and Schubiger, 1965; Kane et al., 1967; Nilsson et al., 1967). The present study was designed, firstly, as a pilot investigation for a comprehensive prospective survey of depressive symptoms during oral contraceptive therapy; secondly, to assess a self-rating scale for measuring such symptoms; and, finally, to determine a cut-off score on the self-rating scale (to be used in the prospective survey) to separate a most severely depressed group.

\section{Methods}

Beck Self-rating Scale.-The questionnaire used was a slightly modified form of the self-rating scale devised by Beck et al. (1961), which was validated in Britain by Metcalfe and Goldman (1965). To the 18 sections of the original scale were added nine similar sections devised by Pichot et al. (1966) to detect depressive symptoms in a non-psychiatric population. The 27 sections of the questionnaire refer respectively to mood, pessimism, feelings of failure, dissatisfaction, guilt, feelings of punishment, disappointment, self-criticism, selfimmolation, crying, irritability, loss of interest in people, decision-making, dissatisfaction with appearance, ability to work, sleep, fatigue, appetite, tension, worry, financial strain, liveliness, concentration, recurring thoughts, restlessness, sleep, and concern for other people. Each section is graded on a three- or four-point scale (where zero score is equivalent to absence of the symptom) and the scores for the individual sections are summed to give the total depression score.

Sample Population.-A total of 270 women attending a clinic run by the Family Planning Association in Surrey were asked to take part in this study; nine refused to co-operate. During January and February 1968 the remaining 261 completed the depression questionnaire by selecting the severity of the item in each section which corresponded to their own feelings during the previous two or three days. They were asked for their ages (the distribution of which is shown in Table I), the date of the first day of their last men-

\footnotetext{
* Brunner Fellow, Mental Health Research Fund. Area Laboratory at West Park Hospital, Epsom, and M.R.C. Neuropsychiatry Unit, West Park Hospital, Epsom, and M.R.C. Neuropsychiatry Medical Research Council Laboratories, Carshalton, Surrey.
† M.R.C. Neuropsychiatry Unit, Medical Research Council Laboratories, Carshalton, Surrey.

‡ Department of Statistics, London School of Economics, London W.C.2.
}

TABle I.-Distribution of Depression Score Versus Age

\begin{tabular}{|c|c|c|c|c|c|c|}
\hline Age: & $18-20$ & $21-25$ & $26-30$ & $31-35$ & $36-40$ & $41+$ \\
\hline $\begin{array}{l}\text { Mean depression score: } \\
\text { Oral contraceptive group }\end{array}$ & 9.6 & $8 \cdot 3$ & & & & \\
\hline Control group & $\begin{array}{c}(12) \\
8 \cdot 2 \\
(8)\end{array}$ & $\begin{array}{l}(67) \\
9 \cdot 2 \\
(21)\end{array}$ & $\begin{array}{c}(25) \\
7.5 \\
(20)\end{array}$ & $\begin{array}{l}(28) \\
10.9 \\
(22)\end{array}$ & $\begin{array}{l}(23) \\
5.5 \\
(11)\end{array}$ & $\begin{array}{l}(13) \\
8.8 \\
(9)\end{array}$ \\
\hline
\end{tabular}

Nore: The numbers in parentheses are the numbers of women in each group. Two women in the control group did not give their ages.

TABLE II.-Distribution of Sample by Contraceptive Method

\begin{tabular}{|c|c|c|c|c|c|}
\hline \multicolumn{3}{|c|}{ Oral Contraceptive Group } & \multicolumn{3}{|c|}{ Control Group } \\
\hline \multicolumn{2}{|c|}{$\begin{array}{l}\text { Brand of Oral } \\
\text { Contraceptive }\end{array}$} & \multirow[b]{2}{*}{$\begin{array}{r}\text { No. } \\
44 \\
42 \\
36 \\
13 \\
5 \\
10 \\
15 \\
3\end{array}$} & \multicolumn{2}{|c|}{$\begin{array}{l}\text { Method of Physical } \\
\text { Contraception }\end{array}$} & \multirow{2}{*}{$\begin{array}{r}\text { No } \\
83 \\
7 \\
3\end{array}$} \\
\hline 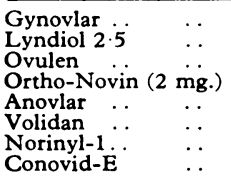 & $\begin{array}{l}. \\
\because \\
\because \\
\therefore \\
\therefore \\
\therefore \\
\cdots\end{array}$ & & $\begin{array}{l}\text { Diaphragm } \\
\text { Intrauterine device } \\
\text { Sheaths }\end{array}$ & $\begin{array}{ll}. & \ldots \\
\cdots & \cdots \\
. & \cdots\end{array}$ & \\
\hline & Total & 168 & & Total & 93 \\
\hline
\end{tabular}

The compositions of the oral contraceptives in this study are as follows: Gynovlar (Schering), Norethisterone acetate $3 \mathrm{mg}$. and ethinyloestradiol $0.05 \mathrm{mg}$. Lyndiol 2.5 (Organon), Ly noestrenol $2.5 \mathrm{mg}$. and mestranol $0.075 \mathrm{mg}$. Ovulen-(Searle), Ethynodiol diacetate $1 \mathrm{mg}$. and mestranol $0.1 \mathrm{mg}$. A Volidan (B.D.H.), Megestrol acetate $4 \mathrm{mg}$. and ethinyloestradiol $0.05 \mathrm{mg}$. Norinyl-1 (Syntex), Norethisterone $1 \mathrm{mg}$. and mestranol $0.05 \mathrm{mg}$. Conovid-E (Searle), Norethynodrel $2.5 \mathrm{mg}$. and mestranol $0.1 \mathrm{mg}$.

strual cycle, and their method of contraception. Those on oral contraceptives were asked when they had started taking them and which brand they used; those using physical methods of contraception formed the control group. The distribution by method of contraception or brand of oral contraceptive is given in Table II.

Analytical Methods.-The analysis of the scores obtained from the questionnaires has been subdivided as follows: (1) analysis of the depression scores of the oral contraceptive and control groups; (2) relation of the depression scores to the day of the menstrual cycle; (3) analysis of the answers to the individual sections of the questionnaire; and (4) relation of depression scores to the time on oral contraceptives.

\section{Results}

\section{Analysis of Depression Scores}

The distribution of the depression scores in the oral contraceptive and control groups is shown in Table III. The distributions for the individual oral contraceptives are shown in Fig. 1. It is readily apparent that $6.6 \%$ of the women on oral contraceptives have depression scores which are higher than any of the scores obtained in the control group.

To analyse the depression scores the three largest oral contraceptive groups-Gynovlar, Lyndiol 2.5, and Ovulenwere distinguished. The remaining oral contraceptive groups were amalgamated (and termed "others") because of their

TABLE III.-Distribution of Depression Scores in Both Groups of Women

\begin{tabular}{|c|c|c|c|c|c|c|c|}
\hline & \multicolumn{7}{|c|}{ Depression Score } \\
\hline & $0-4$ & $5-8$ & $9-12$ & |13-16 & $17-20$ & $21-24$ & $\geqslant 25$ \\
\hline $\begin{array}{l}\text { \% Frequency: } \\
\text { Oral contraceptive group } \\
\text { Control group }\end{array}$ & $\begin{array}{l}31 \cdot 0 \\
34 \cdot 2\end{array}$ & $\begin{array}{l}28 \cdot 0 \\
22 \cdot 4\end{array}$ & $\begin{array}{l}17.5 \\
21.4\end{array}$ & $\begin{array}{r}8 \cdot 3 \\
11.7\end{array}$ & $\begin{array}{l}5 \cdot 9 \\
5 \cdot 3\end{array}$ & $\begin{array}{l}3 \cdot 0 \\
5 \cdot 3\end{array}$ & 6.6 \\
\hline
\end{tabular}




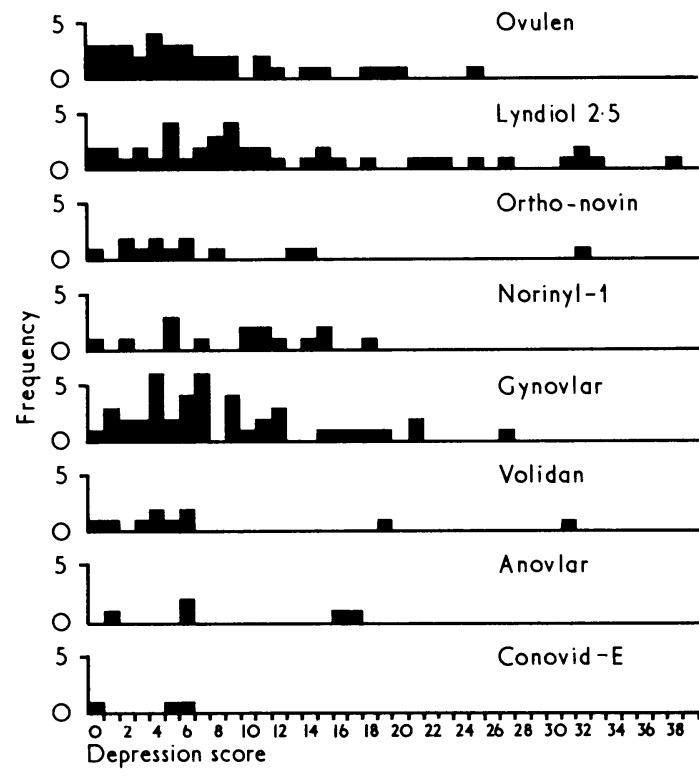

FIG. 1.-Distributions of depression scores for each oral contraceptive.

TABLE IV.-Two-way Classification of Depression Score Versus Oral Contraceptive and Control Groups

\begin{tabular}{|c|c|c|c|c|c|c|c|c|c|}
\hline & & & & & \multicolumn{4}{|c|}{ Depression Score } & \multirow[b]{2}{*}{ Total } \\
\hline & & & & & $0-5$ & $6-11$ & $12-17$ & $>17$ & \\
\hline $\begin{array}{l}\text { Gynovlar... } \\
\text { Lyndiol 2.5 } \\
\text { Ovulen } \quad . . \\
\text { Others } \\
\text { Control }\end{array}$ & $\begin{array}{l}. \\
\because \\
\therefore\end{array}$ & $\begin{array}{l}\ldots \\
\cdots \\
\cdots\end{array}$ & $\begin{array}{l}. \\
\because \\
\because\end{array}$ & $\begin{array}{l}\ldots \\
\cdots \\
\cdots \\
\cdots\end{array}$ & $\begin{array}{l}16 \\
12 \\
18 \\
22 \\
37\end{array}$ & $\begin{array}{l}17 \\
14 \\
11 \\
12 \\
28\end{array}$ & $\begin{array}{r}5 \\
5 \\
3 \\
8 \\
17\end{array}$ & $\begin{array}{r}6 \\
11 \\
4 \\
4 \\
11\end{array}$ & $\begin{array}{l}44 \\
42 \\
36 \\
46 \\
93\end{array}$ \\
\hline & & & & otal & 105 & 82 & 38 & 36 & 261 \\
\hline
\end{tabular}

$\left(x^{2}=12 \cdot 96 ;\right.$ D.F. $=12$, N.S. $)$

For definition of "Others" see text.

comparatively small size. The two-way classification of oral contraceptive and control groups versus depression score is given in Table IV. A $\chi^{2}$ analysis of this table did not indicate significant heterogeneity $\left(\chi^{2}=12 \cdot 96\right.$, D.F. $\left.=12\right)$.

\section{Relation of Depression Scores to Day of Cycle}

This analysis investigated the relation between depression score and several variables-age, time on oral contraceptive, day of the menstrual cycle, and whether completion of the questionnaire occurred during the first five days, the last 10 days, the last five days, or on the last day of the menstrual cycle. Women with amenorrhoea or for whom information about the day of the menstrual cycle was missing were excluded from the analysis.

For the control group it was found that the day of the menstrual cycle contributed significantly to the depression score, and the regression equation

Depression Score $=4.3808+0.2531 \mathrm{D}$

(S.E. of regression coefficient $=0.0991$; residual S.D. $=$ 6.01 ), where $\mathrm{D}=$ day of the menstrual cycle, was obtained. A curvilinear regression did not fit the data significantly better than the straight line. No relation was found between depression score and any of the other variables.

For the oral contraceptive group there was a relation between depression score and whether the questionnaire was completed on the last day of the menstrual cycle. The average depression score for the six women who completed the questionnaire on day 28 or 29 of the menstrual cycle was 21.17 (S.E. of mean $=5.02$ ). The average depression score for the remaining women was 8.65 (S.E. of mean $=0.62$ ). There was no significant relation between the depression score and the day of the menstrual cycle for those women who completed the questionnaire during the first 27 days of the menstrual cycle.

Time on oral contraceptive (see Table V), type of oral contraceptive, and age were not significantly related to the depression score. The women who completed the questionnaire on days 28 and 29 were taking the following oral contraceptives, and their depression scores are shown in parentheses: Ovulen (25), Lyndiol 2.5 (27), Lyndiol 2.5 (10), Lyndiol 2.5 (2), Volidan (31), Ortho-Novin (32).

TaBle V.-Depression Score Versus Time on Oral Contraceptive

\begin{tabular}{|c|c|c|c|}
\hline Time on oral contraceptive (months) .. & $<6$ & $6-12$ & $>12$ \\
\hline lean depression score. & $7 \cdot 3(39)$ & $10 \cdot 6(36)$ & $8 \cdot 1(91)$ \\
\hline
\end{tabular}

Notr: The numbers in parentheses are the numbers of women in each group. Two women did not give the length of time they were on oral contraceptives.

The relation between depression score and the day of the menstrual cycle is illustrated in Fig. 2, where the average depression score in three-day groups up to the twenty-seventh day and the average scores for the twenty-eighth and twentyninth days are shown. The regression line obtained for the

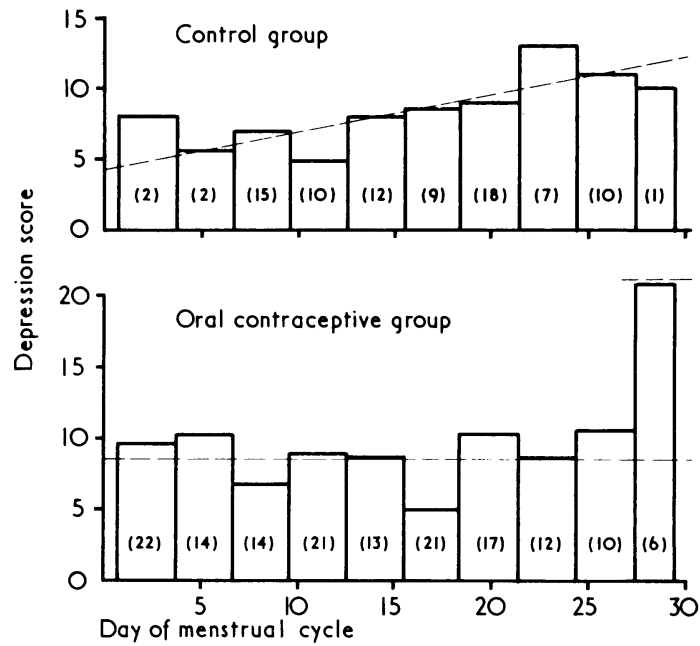

Fig. 2.-Relation between depression scores and day of menstrual cycle. (Number of women in each group given in parentheses.)

control group and the average score for the first 27 days of the cycle for the oral contraceptive group are superimposed on the figure. The variation about the fitted line was greater in the oral contraceptive group than in the control group.

The increase in depression score towards the end of the menstrual cycle in the control group shows that the Beck selfrating inventory is capable of detecting premenstrual depression. It was not possible to demonstrate a similar increase in depression scores during the premenstrual phase in women taking oral contraceptives; however, the high depression scores obtained when the questionnaire was completed on the twenty-eighth or twenty-ninth day of the cycle suggest that premenstrual depression still occurs in some of these women, but that it is limited to the one or two days preceding menstruation.

\section{Analysis of Answers to Sections of Questionnaire}

An analysis of the answers to the questionnaire was performed section by section. The aim was to seek specific depressive symptoms which might differentiate between the different groups shown in Table IV. The subjects were divided according to whether they scored zero or gave a posi- 
TABLE VI.-Contingency Tables for Sections of Questionnaire for which $\chi^{2}$ is Highly Significant (Expected Numbers in Parentheses)

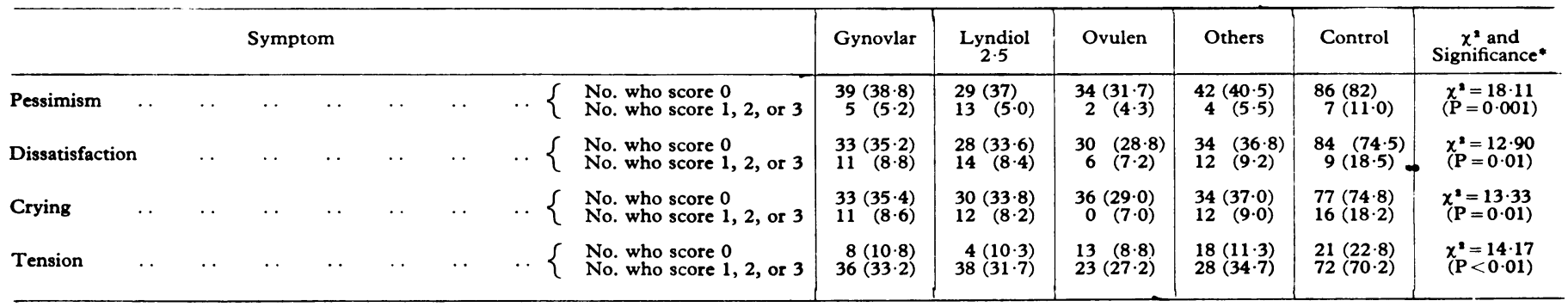

* D.F. $=4$.

tive response-that is, scored 1,2 , or 3 in the section-and the proportions were analysed with the $\chi^{2}$ or an exact test.

Four sections of the questionnaire were answered variously by the five groups with the difference significant at the $1 \%$ level (Table VI). In addition two sections (those referring to feelings of failure and thoughts of harming oneself) were significant at the $5 \%$ level. Since, however, at least one question in 27 would be expected to be significant at the $5 \%$ level by chance alone, it would be unjustifiable to draw any firm conclusions from these two results. The four highly significant results suggest that pessimism, feelings of dissatisfaction, crying, and tension occur more frequently in women taking Lyndiol 2.5 than in the other groups shown in Table VI. Also, these symptoms are apparently not accompanied by other common symptoms of depression, such as sleep disturbance, retardation, and appetite disturbance. It is also indicated in Table VI that fewer women than expected taking Ovulen experience the symptoms listed.

\section{Depression Scores and Time on Oral Contraceptives}

Women using oral contraceptives were divided into two groups according to whether they had been taking them for less than one year or more than one year. The controls formed a third group. For each section the number of women in each group who scored zero was compared with the number who scored 1,2 , or 3 , using either $\chi^{2}$ or an exact test to assess statistical significance.

$\chi^{2}$ attained high significance in the section of the questionnaire referring to thoughts of harming oneself $\left(\chi^{2}=10.66\right.$, D.F. $=2, P<0.01)$. This symptom occurred more often in women taking oral contraceptives for less than one year than either in the control group or in women taking oral contraceptives for longer than one year. In addition two sections of the questionnaire attained a statistical significance of $\mathrm{P}=$ 0.05 (the sections referring to dissatisfaction, $\chi^{2}=7.85$; D.F. $=2$, and difficulty in making decisions, $\chi^{2}=8.85 ;$ D.F. $=2$ ).

\section{Discussion}

Emotional changes are difficult to evaluate. Patients vary in their ability and willingness to describe subtle changes in mood, and observers must be cautious and avoid the introduction of bias into their methods. A self-rating scale facilitates the collection of reliable data, and this showed that $6.6 \%$ of our oral contraceptive group was more depressed than our control group. This agrees with Lewis and Hoghughi (1969), who, using a standardized questionnaire, the Hamilton scale, in 50 women, found that $6 \%$ of the women on oral contraceptives and $1 \%$ of their control group were severely depressed. Herzberg and Coppen (1970) in a prospective study found that $6 \%$ of women taking oral contraceptives described themselves as moderately or severely depressed at some time, whereas only $2 \%$ of a control group had such symptoms.

Of our control group $2 \%$ had depression scores of 23 and over. It is therefore proposed to use a cut-off score of 23 to separate a most severely depressed group in the analysis of the prospective survey. No difference was found between the average depression scores of the oral contraceptive and the control groups, in contrast with Lewis and Hoghughi's findings that women on oral contraceptives were significantly more depressed.

Women taking Lyndiol 2.5 had an increased incidence of certain depressive symptoms-namely, pessimism, feelings of dissatisfaction, crying, and tension-but did not have an increased incidence of all the symptoms commonly associated with depressive illness. By comparison women taking Ovulen had fewer depressive symptoms. This supports an hypothesis that oral contraceptives contribute to the development of certain depressive symptoms.

Some possible sources of error should be listed. Women who were not satisfied with their oral contraceptive are more likely to be attending the Family Planning Clinic. Women were not asked whether they had changed their brand of oral contraceptive at any time, nor were they asked why they had chosen or been advised to use oral contraceptives instead of a physical method of contraception. Doctors might have selected Lyndiol 2.5 for patients they considered to be depression-prone.

It has been suggested that depression is likely to arise as a side-effect of an oral contraceptive which is "too progestational" for a particular patient (British Medical fournal, 1967). Both Lyndiol 2.5 and Ovulen have been classified as intermediate compounds and Gynovlar as a predominantly progestogenic compound according to their effects on the uterine endometrium (Grant, 1967, 1969). Our results suggest that depressive side-effects result from a situation which is probably more complex than alterations in a theoretical oestrogen-progestogen balance.

Several observers (Binks et al., 1962; Goldzieher et al., 1962; Mears and Grant, 1962; Pullen, 1962; Herzberg and Coppen, 1970) have found that premenstrual symptoms are relieved by oral contraceptives. Moos (1968) investigated 839 women and found that though the majority experienced a slight decrease in menstrual symptomatology while taking oral contraceptives, around $10 \%$ had a significant decrease and about the same proportion experienced a significant increase. The results reported here support Moos's findings as well as the earlier findings that depression occurring during the 7 to 10 days before the onset of menstruation is infrequent in women taking oral contraceptives. Pronounced depression, however, related to the last one or two days of the menstrual cycle occurred in some of these women. Four of the most severely depressed women in the oral contraceptive group completed the questionnaire on day 28 of the menstrual cycle. Premenstrual depression is well recognized, and depressive symptoms occurring in premenopausal women, whether they are taking oral contraceptives or not, should be considered in relation to the day of the cycle.

The Committee on Safety of Drugs recently recommended that women should take oral contraceptives containing only $0.05 \mathrm{mg}$. or less of ethinyloestradiol or mestranol. This has resulted in a considerable reduction in the number of compounds in regular use, and consequently should make the evaluation of the side-effects of individual oral contraceptives easier. A longitudinal study in which women taking four 
different oral contraceptives are to be compared with a control group is in progress and the results will be reported in a later communication.

W'e are grateful to the staff and patients of the Carshalton Family Planning Association Clinic for their co-operation, and to Mrs.
J. Ellson and Mrs. M. Russell, who interviewed the patients. Dr. C. C. Spicer, Mrs. Maryse Metcalfe, Dr. Derek Richter, Dr. David M. Shaw, Dr. Martin Vessey, and Mr. Richard Peto gave valuable advice and help with the preparation of the manuscript.

Address reprint requests to Dr. Brenda Herzberg.

\title{
REFERENCES
}

Beck, A. T, Ward, C. H., Mendelson, M., Mock, J., and Erbaugh, J. (1961) Archives of General Psychiatry, 4, 561 .

Binks, R., Cambourn, P., and Papworth, R. A. (1962). Medical fournal of Australia, 49(i), 716.

British Medical fourmal, 1967, 3, 627.

Goldzieher, J. W., Moses, L. E., and Ellis, L. T. (1962). fournal of the American Medical Association, 180, 359.

Grant, E. C. G. (1967). Fournal of Obstetrics and Gynaecology of the British Commonwealth, 74, 908.

Grant, E. C. G. (1969). British Medical fournal, 4, 73.

Hauser, G. A., and Schubiger, V. (1965). Archiv für Gynäkologie, 202, 175. Herzberg, B., and Coppen, A. (1970). British fournal of Psychiatry, 116, $16 i$.
Kane, F. J., Daly, R. J., Ewing, J., and Keeler, M. (1967). British fournal of Psychiatry, 113, 265.

Kaye, B. M. (1963). Fournal of the American Medical Association, 186, 522. Lewis, A., and Hoghughi, M. (1969). British Yournal of Psychiatry, 115, 697. Mears, E., and Grant, E. C. G. (1962). British Medical Fournal, 2, 75.

Metcalfe, M., and Goldman, E. (1965). British fournal of Psychiatry, 111, 240 .

Moos, R.H. (1968). Archives of General Psychiatry, 19, 87.

Nilsson, A, Jacobson, L., and Ingemanson, C.-A. (1967). Acta Obstetrica et Gynaecologica Scandinavica, 46, 537.

Pichot, P., Piret, J., and Clyde, D. J. (1966). Revue de Psychologie Appliquée,

Pullen, D. (1962). British Medical fournal, 2, 1016.

\section{Controlled Clinical Trial of Combined Triodothyronine and Thyroxine in the Treatment of Hypothyroidism}

\author{
R. N. SMITH,* M.D., B.SC., M.R.C.P.ED. ; S. A. TAYLOR† ; J. C. MASSEY, B.SC.
}

\author{
British Medical fournal, 1970, 4, 145-148
}

\begin{abstract}
S ummary: A double-blind cross-over trial of a combined D preparation of triiodothyronine and thyroxine (1:4 ratio) compared with thyroxine alone was conducted with 99 patients previously stabilized on .thyroxine as treatment for hypothyroidism. Four patients were excluded during the trial and eight afterwards owing to gross deficiencies in taking the tablets. Of the remaining 87 patients $42(48 \%)$ had no preference for either medication, 29 (33\%) preferred thyroxine alone, and $16(18 \%)$ the combination. A high incidence of unpleasant symptoms was experienced during the two months' treatment with the combined preparation. The serum protein-bound iodine levels were lowered (mean reduction $1.8 \mu \mathrm{g} . / 100$ ml.) on the combination, but the labelled $T_{3}$-resin sponge uptake values were not altered. and remained in the normal range on both treatments.
\end{abstract}

\section{Introduction}

Thyroxine ( $\mathrm{L}$-thyroxine) and triiodothyronine (3,5,3'-tri-iodo- $\mathrm{L}$ thyronine) are the circulating thyroid hormones in man. Both hormones have been synthesized and each is effective alone in the treatment of hypothyroidism. In contrast to dried thyroid extracts (thyroid B.P., desiccated thyroid U.S.P., thyroglobulin U.S.P.) the composition and potency of triiodothyronine and thyroxine are constant but they differ from each other in physiological action. The dissimilarities of the two hormones are partly due to differences in their binding to protein in both blood and tissues. Thyroxine has a lnnger biological half-life than triiodothyronine and their effects on laboratory tests of thyroid status differ. The serum protein-bound iodine of patients treated with thyroxine is disproportionately high when compared with their metabolic status and low when triiodothyronine alone is used.

Combinations of synthetic triiodothyronine and thyroxine

\footnotetext{
- Lecturer.

$t$ Technician.

Department of Pharmacology and Therapeutics, University of Sheffield, Royal Infirmary, Sheffield S6 3DA

₹ Biochemist, Department of Chemical Pathology, United Sheffield

Hospitals, Children's Hospital, Sheffield S10 2TH.
}

have been introduced in Britain (Taylor, 1961; Taylor et al., 1970) and the United States (Wool and Selenkow, 1965; Selenkow and Wool, 1967), and compared with dried thyroid extracts such preparations have the advantage of constant potency. Furthermore, it has been claimed that a 1:4 combination of triiodothyronine and thyroxine mimics the metabolic action of dried thyroid extracts and also produces biochemical values commensurate with the patient's metabolic status (Selenkow and Wool, 1967). These studies were limited to previously untreated hypothyroid patients and were not adequately controlled. There has been no published report of a valid comparison of combined triiodothyronine and thyroxine with either dried thyroid extract or thyroxine alone, and therefore the present study was undertaken.

\section{Patients and Methods}

Selection of Patients.-Patients treated for hypothyroidism with either 200 or $300 \mu \mathrm{g}$. of L-thyroxine sodium daily for at least six months or longer and judged to be euthyroid were interviewed. The nature and purposes of the clinical trial were explained before asking for the patients' co-operation; those for whom the additional visits would result in financial loss were excluded. The patient's family doctor was notified of the alt -ation in treatment and general design of the trial.

Randok iion.-Patients comprised three groups based on the cause of the hypothyroidism: spontaneous, following thyroid surgery, or after radioiodine therapy. The sequence of treatment within each group had been randomized and coded by an independent pharmacist so that each patient received thyroxine ( $\left.T_{4}\right)$ alone for two months and combined triiodothyronine and thyroxine $\left(\mathrm{T}_{3} / \mathrm{T}_{4}\right)$ for two months in random rotation. The tablets were issued from the hospital pharmacy, but the doctor, technical staff, dispensing pharmacists, and patient were not aware of their identity.

Dosage.-When on L-thyroxine sodium the same dose $(200$ or $300 \mu \mathrm{g}$.) was prescribed for each patient as they had received before the trial. On the combination of hormones the tablets were identical in appearance and taste to the $T_{4}$ ablets and the same number were given daily (two or three) as were prescribed before the study and in the thyroxine part 